\title{
Indonesia dalam Pusaran Globalisasi dan Pengaruhnya Terhadap Krisis Moral dan Karakter
}

\author{
Gema Budiarto \\ Fakultas IImu Budaya Universitas Diponegoro \\ E-mail : history.gema@gmail.com \\ Naskah diterima 20 Maret 2020, Revisi 15 April 2020, Terbit 19 April 2020
}

\begin{abstract}
Abstrak
DOI: doi.org/10.21107/pamator.v13i1.6912

Globalisasi pelan tetapi pasti mampu merubah segala aspek kehidupan manusia, dari sosial, politik, pendidikan dan lain-lain. Dampak dari globalisasi sudah tidak bisa terbendung lagi, efek dari globalisasi dapat dilihat dalam masyarakat, seperti terjadinya krisis moral dan karakter yang terjadi saat ini. Moral dan karakter bangsa Indonesia sangat lemah, seperti sering terjadinya korupsi, anarkisme, dan konflik yang berujung pada kekerasan individual atau golongan, hal semacam ini akan bertentangan dengan Pancasila sebagai pandangan hidup bangsa Indonesia dan juga cerminan dari karakter bangsa Indonesia. Tulisan ini menjelaskan tentang krisis moral dan karakter yang tengah dialami oleh bangsa Indonesia karena pengaruh dari globalisasi, sehingga terjadi degradasi budaya yakni kemunduran, kemrosotan, dan penurunan budaya yang dapat mengancam keutuhan dan ketahanan budaya Indonesia.
\end{abstract}

Kata Kunci: globalisasi, moral, karakter

\section{PENDAHULUAN}

Karakter merupakan ciri khas yang identik dengan suatu hal atau ciri khas yang membedakan antara satu dengan yang lainnya. Karakter berkaitan erat dengan tabiat seseorang dalam kehidupannya, sehingga karakter dapat dibagi menjadi dua yakni, karakter yang buruk dan karakter yang mulia. Pembinaan karakter yang mulia haruslah dilakukan dan diterapkan, untuk membangun norma-norma sosial dalam masyarakat. Terutama masyarakat Indonesia, telah tercermin sejak dahulu Indonesia merupakan salah satu negara yang memiliki adat/kepribadian ketimuran. Adat/kepribadian ketimuran sendiri memiliki ciri khas, menjunjung tinggi nilai, moral, dan etika dalam masyarakat, memiliki rasa toleransi yang tinggai, ramah-tamah, dan saling menghargai serta saling tolongmenolong. Apalagi Indonesia memiliki filosofi Pancasila sebagai pandangan hidup bangsa. Sudah dapat diketahui dengan jelas karakter bangsa Indonesia haruslah sesuai apa yang termakna dalam sila Pancasila, seperti Ketuhanan, Kemanusiaan, Persatuan, Permusyawarahan, dan Keadilan sosial. Tetapi saat ini seakan-akan karakter manusia Indonesia tersebut menghilang bersamaan dengan lahirnya globalisasi. Banyak orang-orang terutama anak muda Indonesia yang telah meninggalkan karakter mereka sebagai manusia Indonesia, nilai dan moral pun tidak mereka perdulikan. Maka dapat dikatakan Indonesia saat ini mendapat tantangan besar untuk menghadapi krisis moral dan krisis karakter.

Globalisasi memiliki tanggung jawab atas tergerusnya nilai-nilai moral dan karakter, hal ini merupakan ancaman yang serius dan perlu mendapat perhatian dari berbagai pihak. Globalisasi sendiri memiliki pengertian terbentuknya sebuah penyatuan masyarakat di seluruh dunia (global) karena adanya kemajuan teknologi dan komunikasi yang dapat mempersingkat interaksi antar wilayah satu dengan yang lain. Maka dari itu, globalisasi juga akan membawa pengaruh asing untuk masuk ke Indonesia.

Degradasi budaya akan terjadi jika suatu negara tidak memiliki filter yang kuat untuk menyaring budaya asing yang masuk, sehingga akan melemahkan budaya lokal dan bangkitnya budaya asing. Mungkin banyak orang memiliki pendapat yang biasabiasa saja akan masuknya budaya asing ke Indonesia dan bukan menjadi ancaman yang serius, padahal hal semacam ini merupakan ancaman besar yang menyangkut akan jati diri bangsa Indonesia. Meskipun begitu, globalisasi tidak selalu menjadi yang terburuk bagi bangsa Indonesia, globalisasi juga dapat membawa hal positif seperti berkembangnya ilmu 
pengetahuan, teknologi informasi dan komunikasi sehingga mempermudah dan memperbaiki kualitas pendidikan dalam proses pembelajaran seperti berkembangnya e-learning, mendukung terciptanya kursus online, memfasilitasi terbangunnya sistem tutorial bagi pendidikan jarak jauh, membuka perpustakaan elektronik, dan pembelajaran dengan alat bantu komputer (Asmani, 2011).

\section{HASIL DAN PEMBAHASAN \\ Gagalnya Pembinaan Moral}

Moral merupakan perilaku dalam kehidupan manusia yang dapat membedakan manakah suatu hal baik atau hal yang buruk. Suatu hal yang baik di suatu wilayah belum tentu baik pula di wilayah yang lainnya, jadi moral tersebut memiliki ukuran dan perbedaan di masing-masing wilayah. Tetapi jika masuk dalam konteks Pancasila di Indonesia, moral Pancasila akan tetap sama di daerah-daerah dalam wilayah Indonesia. Moral sendiri berkaitan erat dengan perilaku seseorang dalam kelompok atau masyarakat. Menurut Meriam-Webster pengertian moral dibagi menjadi tiga, yakni: (1) concerning or relating to what is right and wrong in human behavior; (2) based on what you think is right and good; and (3) considered right and good by most people: agreening with a standard of right behavior.

Saat ini dengan realita yang ada dalam masyarakat terlebih lagi para generasi muda, sebagian dari mereka seakan-akan sudah tidak memperhatikan moral. Mereka hanya menuntut kesenangan sesaat dan tidak memperhatikan lebih matang lagi apa yang mereka lakukan. Sikap acuh melatarbelakangi sifat-sifat dari generasi muda saat ini, dengan istilah "hidup $m u$ adalah hidup mu, hidup ku adalah hidup ku" mereka mengacuhkan saran dan kritik yang sekiranya membangun. Generasi muda saat ini banyak yang masuk dalam kubangan hitam globalisasi dengan mengandalkan "trend". Pergaulan bebas semakin merebak dikalangan muda, sehingga dampak dari kebebasan tersebut berbuah akibat seperti: narkoba, sex bebas/pelacuran, homosex, dan lain-lain menjadi fenomena yang sudah tidak bisa disembunyikan. Kejadian-kejadian semacam itu sudah sangat jelas tidak sesuai dengan nilai-nilai kehidupan bangsa
Indonesia dan nilai-nilai dalam agama, hal ini sudah mengindikasikan bahwa memburuknya moral dalam kehidupan.

Mengutip dari Herlini Amran angota komisi X, mengatakan "Menurut saya, saat ini Indonesia sudah dalam kondisi 'Darurat Moral Baik'. Pemerintah harus segera melakukan evaluasi yang komperhensif terkait pelaksanaan pendidikan karakter atau muatan moral yang mengejawantahkan sistem pendidikan nasional kita" (Lensa Indonesia, 2016).

Proses pembinaan kognitif (pengetahuan) lebih ditekankan dalam proses pembelajaran di sekolah sehingga pembinaan moral seakan-akan terabaikan, meskipun itu diajarkan hanya sebatas teori tanpa ada hasil yang nyata. Pembinaan moral tidak hanya tugas guru disekolah, tetapi tugas bersama dan tanggung jawab bersama semua lapisan masyarakat, terutama keluarga. Tetapi semua ini kembali pada realitas yang ada, masyarakat masih lebih mengutamakan nilai akademik yang tinggi dari pada nilai moral. Pendidikan akan percuma jika hanya mengandalkan nilai akademik tanpa diimbangi pembentukan karakter moral yang kuat (Triatmanto, 2010).

Krisis moral yang dialami oleh Indonesia saat ini merupakan efek negatif dari globalisasi, meskipun begitu kita tidak boleh mengkambing hitamkan globalisasi. Efek dari globalisasi sendiri tidak terus-menerus berdampak negatif, itu semua tergantung dari kita sendiri bagaimana menyikapi dan membawa globalisasi menuju hal yang positif. Pengaruh dari budaya asing yang masuk melalui media-media sosial (internet) juga sangat perperan besar dalam kemrosotan moral di Indonesia, dalam hal ini budaya asing tersebut budaya yang tidak sesuai dengan pandangan masyarakat Indonesia, tetapi tidak semua budaya asing ditolak masuk ke Indonesia, jika budaya asing tersebut sesuai dengan pandangan hidup bangsa Indonesia maka juga akan diterima. Masuknya budaya asing sudah tidak terfilter lagi oleh kalangan muda bangsa Indonesia, ini semua demi atas nama kesenangan dan atas nama modernitas. Globalisasi sendiri seperti lawan dan kawan. Dalam konteks lawan globalisasi memberikan dampak buruk terhadap kehidupan budaya lokal sehingga akan menghilangkan jati diri bangsa, sedangkan 
dalam konteks kawan globalisasi memberikan manfaat dan kemudahan bagi kehidupan masyarakat untuk melakukan aktivitas sehari-hari.

Semakin lama nilai adat/kepribadian ketimuran bangsa Indonesia mulai tergerus oleh zaman. Perkembangan zaman dan perkembangan ilmu pengetahuan yang dibarengi juga dengan berkembangnya teknologi dan informasi tidak serta merta harus membunuh moral bangsa. Semakin berkembangnya media teknologi dan informasi tersebut sudah tidak dapat dielakkan lagi oleh semua pihak. Perkembangan ini akan terus mengalami perubahan-perubahan yang disesuaikan dengan kebutuhan global, untuk mempermudah kejar manusia dalam kerjanya, tidak menutup kemungkinan perkembangan tersebut juga akan membawa pengaruh-pengaruh asing yang negatif masuk ke Indonesia. Perkembangan teknologi dan informasi memang tuntutan, tetapi nilai-nilai (value) luhur budaya bangsa haruslah tetap terjaga sebagai kehormatan diri kita dan kehormatan bangsa.

Pembinaan moral harus lebih ditingkatkan, agar karakter dan jati diri bangsa Indonesia tidak hilang ditelan efek negatif dari globalisasi. Pembinaan moral Pancasila adalah pokok yang menjadi dasar acuan untuk membina moral manusiamanusia Indonesia, karena Pancasila adalah pandangan hidup bangsa Indonesia, dan juga sebagai pembentuk karakter bangsa. Pancasila sebagai pandangan hidup bangsa merupakan kristalisasi nilainilai yang hidup dalam masyarakat Indonesia, sehingga pandangan tersebut dijunjung tinggi oleh warga negara Indonesia, karena pandangan tersebut telah berakar pada budaya Indonesia (Kaelan, 2010). Selanjutnya, Budiyono (2014) menjelaskan empat pokok Pancasila sebagai pandangan hidup:

1. Pancasila digunakan sebagai pedoman hidup untuk bersikap dan bertingkahlaku dalam kehidupan bermasyarakat, berbangsa, dan bernegara.

2. Pancasila tumbuh dan berkembang bersamaan dengan tumbuh dan berkembangnya bangsa Indonesia.

3. Pancasila memiliki sanksi sosial dan sanksi moral.
4. Pancasila sudah tidak mungkin dipisahkan dari kehidupan bangsa Indonesia, karena sudah merupakan "Jiwa Kepribadian Bangsa Indonesia".

Pancasila memiliki peran utama dalam kehidupan bangsa Indonesia, yakni sebagai Dasar Negara, maka dari itu Pancasila perlu dimengerti, dipahami, dan diamalkan dalam kehidupan bermasyarakat, sehingga dari sini Pancasila menjadi acuan proses pembangunan karakter bangsa (Suranto, 2013).

Mengacu pada sila pertama dalam Pancasila, Ketuhanan Yang Maha Esa, dari sini dapat dilihat bahwa, manusia Indonesia harus meyakini adanya Tuhan. Setiap mereka yang bertuhan dan beragama pasti memiliki moral, karena di dalam ajaran agama apapun yang ada di Indonesia, pasti diajarkan pada umatnya untuk menjadi manusia yang bermoral. Di dalam agama memuat aturan-aturan dalam kehidupan manusia, sehingga manusia tersebut tidak salah dalam bertindak atau pun bertutur dengan sesamanya, termasuk di dalamnya (agama) terdapat pembinaan moral kepada umatnya.

Agama memiliki peran yang cukup besar untuk membina budi pekerti, akhlak mulia, etika, dan moral manusia, karena hal itu merupakan tanggung jawab dirinya dengan Tuhan, telah dijelaskan di atas, bahwa seseorang yang beragama dan memahami agamanya pasti memiliki kepribadian yang baik terhadap lingkungan masyarakat. Maka dari itu pembinaan moral melalui bembekalan ilmu agama juga harus digalakkan oleh para pemuka agama, selama bembekalan tersebut tidak bertentangan dengan Pancasila, UUD 1945, NKRI, dan Bhinneka Tunggal lka.

\section{Membangun Karakter Bangsa}

Telah dijelaskan di atas, karakter merupakan ciri khas dari seseorang atau suatu hal yang membuatnya berbeda dengan yang lain. Kejiwaan, watak, sfat, tabiat, dan perilaku adalah beberapa unsur yang ada dalam karakter. Karakter dapat dibagi menjadi dua, yakni karakter yang positif dan karakter yang negatif. Karakter positif bisa seperti penyabar, penyayang, jujur, dan lain-lain, sedangkan karakter negatif seperti pemarah, pendendam, licik, 
dan lain-lan. Karakter yang negatif tersebut dapat dirubah menjadi positif, melalui tiga cara yang harus diterapkan secara bersama, yakni niatan, kesadaran, dan komitmen. Niat adalah kunci pertama untuk mengawali perubahan karakter orang untuk menjadi lebih baik, dengan niat merupakan kesunguhan seseorang untuk melaksanakan suatu hal.

Kesadaran disini berhubungan dengan pikiran, perasaan, dan perilaku, jadi untuk merubah ke arah yang lebih baik orang tersebut patut untuk menyadari tindakan awalnya terlebih dahulu, apakah tindakannya sudah mencerminkan kebaikan atau belum. Maka dari itu orang tersebut haruslah mengubah dan memperbaiki polapola tindakannya menjadi lebih baik dari sebelumnya, atas dasar kebaikan bersama. Terakhir adalah komitmen, komitmen merupakan ikatan atau janji untuk bertanggung jawab secara penuh terhadap apa yang telah dilaksanakannya, jadi komitmen untuk merubah karakter menjadi lebih baik harus menjadi sebuah tanggung jawab setiap orang untuk mengubah karakternya menjadi lebih baik lagi. Lalu kepada siapakah seorang itu berkomitmen? Terutama berkomitmen pada diri sendiri untuk kebaikan bersama, terlebih lagi berkomitmen pada Tuhan. Merubah karakter memang sangat sulit, meskipun begitu bukan berarti tidak bisa dirubah, karakter dapat dirubah selama ada niat dari orang tersebut untuk berubah (intern) dan orang lain untuk merubah (ekstern).

Merubah karakter negatif menjadi karakter yang lebih baik dan karakter yang unggul memang sangat diperlukan. Tidak hanya baik kepada diri sendiri tetapi juga kepada orang lain. Membangun karakter diri menjadi lebih baik juga akan berimbas pada pembangun karakter bangsa. Menurut Kebijakan Nasional Pembangunan Karakter Bangsa sebagai pelaksanaan amanat Rencana Pembangunan Jangka Panjang Nasional Tahun 2005-2025 dan sekaligus pelaksanaan arahan Presiden Republik Indonesia (2010), ada lima point penting mengapa membangun karakter bangsa begitu penting, yaitu: filosofis, ideologis, normatif, historis, dan sosiokultural. Secara filosofis, hakikatnya karakter sangat dibutuhkan oleh suatu bangsa, karena bangsa yang akan tetap berjaya hanya bangsa yang memiliki karakter bangsa tangguh dan kuat. Secara ideologis, pembangunan karakter merupakan wujud dari penerapan ideologi Pancasila. Secara normatif, pembangunan karakter merupakan wujud dari tujuan negara Indonesia yang sesuai dengan pembukaan UUD 1945 alinea ke empat, yakni melindungi segenap bangsa indonesia dan seluruh tumpah darah Indonesia; memajukan kesejahteraan umum ; mencerdaskan kehidupan bangsa ; dan ikut melaksanakan ketertiban dunia yang berdasarkan kemerdekaan, perdamaian abadi dan keadilan sosial. Secara historis, pembangunan karakter bangsa merupakan proses yang tidak akan berhenti, dari zaman penjajahan sampai saat ini dan seterusnya. Secara sosiokultural, pembangunan karakter bangsa adalah hal yang harus dilakukan oleh suatu bangsa yang multikultural.

Pembangunan karakter tersebut memiliki hasil akhir yang dapat diharapkan, sehingga akan didapatkan karakter manusia Indonesia yang tangguh. Berikut ini merupakan karakter yang menjadi indikator ketercapaian, (a) Karakter yang bersumber dari olah hati, antara lain beriman dan bertakwa, jujur, amanah, adil, tertib, taat aturan, bertanggung jawab, berempati, berani mengambil resiko, pantang menyerah, rela berkorban, dan berjiwa patriotik; (b) Karakter yang bersumber dari olah pikir antara lain cerdas, kritis, kreatif, inovatif, ingin tahu, produktif, berorientasi Ipteks, dan reflektif; (c) Karakter yang bersumber dari olah raga/kinestetika antara lain bersih, dan sehat, sportif, tangguh, andal, berdaya tahan, bersahabat, kooperatif, determinatif, kompetitif, ceria, dan gigih; dan (d) Karakter yang bersumber dari olah rasa dan karsa antara lain kemanusiaan, saling menghargai, gotong royong, kebersamaan, ramah, hormat, toleran, nasionalis, peduli, kosmopolit (mendunia), mengutamakan kepentingan umum, cinta tanah air (patriotis), bangga menggunakan bahasa dan produk Indonesia, dinamis, kerja keras, dan beretos kerja.

Karakter dan budaya bangsa harus dipertahankan, karena merupakan pembeda antara bangsa yang satu dengan yang lainnya, sekaligus merupakan sebuah ciri khas dari suatu bangsa. Maka dari itu untuk mempertahankan eksistensi bangsa 
Indonesia dan memperkuat jati diri bangsa perlu melakukan pembangunan karakter yang merupakan upaya perwujudan amanat Pancasila dan Pembukaan UUD 1945 (Rachmah, 2013). Pembangunan karakter bangsa menjadi bagian dalam visi pembangunan nasional yang tertuang dalam Rencana Pembangunan Jangka Panjang tahun 2005-2025, yakni mewujudkan Indonesia sebagai bangsa yang maju, mandiri, dan adil sebagai landasan bagi tahap pembangunan berikutnya menuju masyarakat adil makmur dalam NKRI berdasarkan Pancasila dan Undang-Undang Dasar Negara Republik Indonesia Tahun 1945. Untuk mewujudkan visi tersebut, maka pembangunan jangka panjang diarahkan untuk mengemban misi:

1. Mewujudkan masyarakat Indonesia yang berakhlak mulia, bermoral, beretika, berbudaya, dan berkeadaban;

2. Mewujudkan bangsa yang berdaya saing untuk mencapai masyarakat yang lebih makmur dan sejahtera;

3. Mewujudkan Indonesia yang demokratis, berlandaskan hukum, dan berkeadilan;

4. Mewujudkan rasa aman dan damai bagi seluruh rakyat serta terjaganya keutuhan wilayah NKRI dan kedaulatan negara dari ancaman, baik dari dalam negeri maupun luar negeri;

5. Mewujudkan pembangunan yang lebih merata dan berkeadilan;

6. Mewujudkan Indonesia yang asri dan lestari;

7. Mewujudkan Indonesia sebagai negara kepulauan yang mandiri, maju, kuat, dan berbasiskan kepentingan nasional;

8. Mewujudkan Indonesia berperan penting dalam pergaulan dunia internasional (Pemerintah Republik Indonesia, 2010).

Membangun dan mengembangkan karakter merupakan hal yang sangat penting bagi keberlangsungan suatu bangsa. Pengembangan tersebut dilakukan secara terus menerus, dan melalui perencanaan yang matang (Afandi, 2011). Membangun karakter berawal dari keluarga. Keluarga merupakan awal dari anak untuk tumbuh dan berkembang, keluarga dapat memberikan bimbingan berupa keteladanan dan kebaikan dalam kehidupan. Peranan keluarga akan mendukung anak tersebut untuk dapat berinteraksi dengan masyarakat yang lebih luas. Selain keluarga, pendidikan (lingkungan sekolah) memberikan pengaruh besar dalam pembangunan dan pengembangan karakter. Pendidikan adalah usaha sadar dan terencana untuk mewujudkan suasana belajar dan proses pembelajaran agar peserta didik secara aktif mengembangkan potensi dirinya untuk memiliki kekuatan spiritual keagamaan,pengendalian diri, kepribadian, kecerdasan, akhlak mulia, serta keterampilan yang diperlukan dirinya, masyarakat, bangsa dan negara (UndangUndang Republik Indonesia Nomor 20 Tahun 2003).

Sekolah melalui program yang telah dicetuskan oleh pemerintah dapat memberikan peserta didiknya pendidikan karakter (character education). Pendidikan karakter merupakan pendidikan yang berupaya untuk menanamkan nilai-nilai luhur kepada seluruh warga sekolah (kepala sekolah, guru, staf karyawan, dan siswa) yang meliputi komponen pengetahuan, kesadaran, dan tindakan untuk melaksanakan nilai tersebut, maka dari itu dalam pelaksanaannya semua komponen sekolah harus terlibat dan dilibatkan. Terutama pendidikan karakter yang ditujukan pada siswa, maka dari itu tugas guru harus mampu mempengaruhi karakter peserta didik.

Sebagai pembentuk watak peserta didik, guru harus menunjukkan keteladanan. Segala hal tentang perilaku guru hendaknya menjadi contoh bagi peserta didik (Suyitno, 2012). Kemdiknas pun telah menyusun acuan 18 nilai karakter bangsa yang menjad acuan dalam pendidikan di Indonesia, antara lain adalah 1) religius; 2) jujur; 3) toleransi; 4) disiplin; 5) kerja keras; 6) kreatif; 7) mandiri; 8) demokratis; 9) rasa ingin tahu; 10) semangat kebangsaan; 11) cinta tanah air; 12) menghargai prestasi; 13) bersahabat/komunikatif; 14) cinta damai; 15) gemar membaca; 16) peduli lingkungan; 17) peduli sosial; dan 18) tanggung jawab (Kemdiknas, 2010). Selain keluarga dan sekolah, masyarakat merupakan salah satu bagian yang tidak bisa dipisahkan dalam pembangunan karakter. $\mathrm{Di}$ dalam masyarakat terdapat berbagai macam individu yang berbeda-beda, karena masyarakat bersifat heterogen, secara langsung maupun tidak langsung masyarakat telah mengajarkan nilai-nilai dan 
etika, sehingga akan terbentuk karakter moral seseorang yang berbudaya dan beradab. Pembangunan karakter dapat dilakukan melalui keluarga, sekolah dan masyarakat, karakter yang dibutuhkan dan diharapkan adalah karakter yang unggul, kuat, dan bermoral sehingga memiliki jati diri pribadi tangguh yang akan berpengaruh pula pada ketangguhan karakter bangsa.

\section{Peran Masyarakat dalam Membentuk Moral dan Karakter}

Saat ini memang sepertinya Indonesia mengalami krisis moral, untuk menanggulangi krisis tersebut, maka diperlukan pemantapan pendidikan karakter dan juga pendidikan agama. Adanya krisis moral tersebut mendapat perhatian serius dari beberapa pihak, seperti KH Sadeli, berpendapat bahwa, "perkembangan teknologi informasi yang sangat cepat telah menggeser norma kepantasan yang selama ini dipegang erat masyarakat. Maka, saat ini mulai nampak dampak buruk dari krisis moralitas ini" (Antara News, 2016),

Seperti yang telah dijelaskan di atas, perkembangan teknologi selain membawa kemudahan dalam beraktifitas, di sisi lain memiliki dampak negatif yang cukup mengkhawatirkan, terutama lunturnya moral, akhlak, dan nilai-nilai kemanusiaan dalam masyarakat. Maka dari itu, Indonesia sebagai negara yang beradab dan berbudaya haruslah memiliki filter yang kuat untuk membendung pengaruh luar yang negatif agar tidak merusak moral bangsa.

Pendidikan karakter dan agama memang sangat dibutuhkan untuk mengobati masyarakat dari krisis moral yang telah menjadi penyakit akut bangsa ini, Amien Rais berpendapat bahwa, "permasalahan itu merupakan tanggung jawab masyarakat Indonesia dan benar-benar harus ditangani dengan serius, penuntasannya dengan memperkuat lagi nilai-nilai luhur adat dan agama yang belakangan jadi hal kesekian dalam kehidupan" (Metro TV News, 2016). Amien Rais telah menyinggung bahwa, pendidikan agama sangat diperlukan, karena pendidikan agama mengajarkan akhlak mulia pada setiap orang, selain itu pendidikan agama mengajarkan kepada manusia manakah tindakan yang baik dan buruk atau yang pantas dan tidak pantas karena dasar ajaran agama adalah kebaikan, maka hasil akhirnya akan tercipta manusia yang baik untuk dirinya, orang lain, dan Tuhan. Di sebutkan pula dalam peraturan pemerintah No 55 Tahun 2007 tentang pendidikan agama dan pendidikan keagamaan, menjelaskan bahwa pendidikan agama adalah pendidikan yang memberikan pengetahuan dan membentuk sikap, kepribadian, dan keterampilan peserta didik dalam mengamalkan ajaran agamanya, yang dilaksanakan sekurang-kurangnya melalui mata pelajaran/kuliah pada semua jalur, jenjang, dan jenis pendidikan.

Agar pendidikan-pendidikan tersebut dapat berjalan sesuai harapan maka perlu pengawasan dari semua pihak, terutama pengawasan dari masyarakat itu sendiri, karena masyarakat sebagai tempat dimana implementasi dari pendidikan karakter dan agama tersebut diterapkan. Dalam lingkungan masyarakat perlu diupayakan agar terjadi proses penguatan karakter dari seluruh elemen masyarakat terhadap perilaku individu lainnya (Kemdiknas, 2010). Masyarakat nantinya akan memberi kritik dan saran yang membangun kepada mereka yang mungkin tindakannya kurang dapat diterima oleh masyarakat umum. Masyarakat perlu tanggap dan penuh perhatian dengan gejala-gejala sosial terutama krisis moral saat ini, jangan sampai masyarakat hanya diam menjadi penonton sehingga membiarkan perilaku-perilaku seseorang tersebut menyimpang dari adab bangsa Indonesia, jika masyarakat tidak tanggap tidak dimungkinkan lagi akan lebih memperparah krisis moral bangsa. Masyarakat perlu memberi evaluasi dan koreksi, masyarakat pula yang menjadi pemantau utama, maka dari itu membangun karakter harus lebih digalakkan karena karakter yang kuat akan menentukan masa depan bangsa dengan moral yang berbudi luhur.

\section{KESIMPULAN}

Tidak dapat dipungkiri lagi bahwa saat ini kemajuan teknologi semakin canggih dan Indonesia pun juga tidak luput dari berkembangnya kemajuan teknologi tersebut, kemajuan teknologi memang seharusnya membawa efek positif bagi kehidupan, tetapi kemajuan tersebut juga memiliki sisi gelap atau efek negatif seperti 
rendahnya moral seseorang terutama para remaja. Realita yang terjadi dalam masyarakat sekarang ini banyak fenomena rendahnya moral terutama para remaja. Pendidikan karakter, yang telah dicanangkan seakan-akan tidak ada hasilnya, meskipun begitu proses pendidikan karakter memang membutuhkan waktu yang tidak lama tetapi setidaknya hasil dari apa yang telah dicanangkan dapat terlihat meskipun sedikit. Pendidikan telah dapat menghasilkan kualitas kognitif (ranah pengetahuan) menjadi unggul, tetapi kualitas afektif (ranah sikap) tidak berkembang. Realitanya memang pendidikan karakter tidak akan menyentuh semua individu, hanya individu-individu yang sadar akan moral, etika, dan kebaikan saja yang dapat menerimanya. Pendidikan agama juga tidak kalah pentingnya, karena pendidikan agama mengajarkan akhlak, moral, dan etika umatnya, sehingga menjadi manusia yang baik dan beradab. Peran serta masyarakat sangatlah dibutuhkan. Masyarakat sebagai evaluator nantinya akan memberikan kritikan dan saran kepada sesamanya. Indonesia harus memiliki karakter bangsa yang kuat dan tangguh, karakter manusia Indonesia yang memiliki jati diri Pancasila.

\section{DAFTAR PUSTAKA}

Afandi, R. 2011. Integrasi Pendidikan Karakter dalam Pembelajaran IPS di Sekolah Dasar. Pedagogia. Vol 1 No 1. 85-98 pp.
Asmani, J.M. 2011. Tips Efektif Pemanfaatan Teknologi Informasi dan Komunikasi dalam Dunia Pendidikan. Yogyakarta: Diva Press.

Budiyono, K. 2014. Pendidikan Pancasila untuk Perguruan Tinggi. Bandung: Alfabeta.

Kaelan. 2010. Pendidikan Pancasila "Edisi ke 9". Yogyakarta: Paradigma.

Kemdiknas. 2010. Pengembangan Pendidikan Budaya dan Karakter Bangsa. Jakarta: Pusat Kurikulum.

2010. Kerangka Acuan Pendidikan Karakter Tahun Anggaran 2010. Jakarta: Direktorat Jenderal Pendidikan Tinggi.

Pemerintah Republik Indonesia. 2010. Kebijakan Nasional Pembangunan Karakter Tahun 2005-2025. Jakarta: Pemerintah Republik Indonesia.

Rachmah, H. 2013. Nilai-nilai dalam Pendidikan Karakter Bangsa yang Berdasarkan Pancasila dan UUD 1945. E-Journal WIDYA NonEksakta. Vol 1 No 1.

Suranto A.W. 2013. Pancasila Sebagai Paradigma Pembangunan Karakter Bangsa. Jurnal Dialog Kebijakan Publik. Vol 10.

Suyitno, I. 2012. Pengembangan Pendidikan Karakter dan Budaya Bangsa Berwawasan Kearifan Lokal. Jurnal Pendidikan Karakter. Vol 2. No 1.

Triatmanto. 2010. Tantangan Implementasi Pendidikan Karakter di Sekolah. Jurnal Cakrawala Pendidikan. Edisi Khusus Dies Natalis UNY. 
